\title{
COVID-19 pneumonia and pneumothorax: case series
}

\author{
Leyla TALAN ${ }^{1}$ (ID) \\ F. Gonca SSASAL \\ SOLMAZ ${ }^{2}(\mid D)$ \\ Uğur ERCAN ${ }^{2}(I D)$ \\ Irem AKDEMIR \\ $\operatorname{KALKAN}^{4}(I D)$ \\ Bülent Mustafa \\ YENIGÜN ${ }^{3}(I D)$ \\ Cabir YÜKSEL ${ }^{3}$ (ID) \\ N. Defne ALTINTAŞ ${ }^{1}$ (ID)
}

\footnotetext{
${ }^{1}$ Department of Internal Medicine, Division of Intensive Care, Ankara University Faculty of Medicine, Ankara, Turkey

${ }^{1}$ Ankara Üniversitesi Tıp Fakültesi, İç Hastalıkları Anabilim Dalı, Yoğun Bakım Bilim Dalı, Ankara, Türkiye

2 Division of Intensive Care, Ankara University Faculty of Medicine, Ankara, Turkey

${ }^{2}$ Ankara Üniversitesi Tıp Fakültesi, Yoğun Bakım Bilim Dalı, Ankara, Türkiye

${ }^{3}$ Department of Thoracic Surgery, Ankara University Faculty of Medicine, Ankara, Turkey

${ }^{3}$ Ankara Üniversitesi Tıp Fakültesi, Göğüs Cerrahisi Anabilim Dalı, Ankara, Türkiye

${ }^{4}$ Department of Infection Diseases and Clinical Microbiology, Ankara University Faculty of Medicine, Ankara, Turkey

${ }^{4}$ Ankara Üniversitesi Tıp Fakültesi, Enfeksiyon Hastalıkları ve Klinik Mikrobiyoloji Anabilim Dalı, Ankara, Türkiye
}

Cite this article as: Talan L, Sasal Solmaz FG, Ercan U, Akdemir Kalkan I, Yenigun BM, Yuksel C, et al. COVID-19 pneumonia and pneumothorax: case series. Tuberk Toraks 2020;68(4):437-443.

Yazışma Adresi (Address for Correspondence)

\section{Dr. Leyla TALAN}

Ankara Üniversitesi Tıp Fakültesi,

İç Hastalıkları Anabilim Dalı,

Yoğun Bakım Bilim Dalı,

ANKARA - TÜRKIYE

e-mail: leylatalan@gmail.com

CCopyright 2020 by Tuberculosis and Thorax

Available on-line at www.tuberktoraks.org.com

\section{ABSTRACT}

COVID-19 pneumonia and pneumothorax: case series

Barotrauma is a commonly reported complication in critically ill patients with ARDS caused by different etiologies, it's rate is reported to be around \% 10 . Pneumothorax/pneumomediastinum in COVID-19 patients seem to be more common and have different clinical characteristics. Here we report 9 patients who had pneumothorax and/or pneumomediastinum during their stay in the ICU.

Patients who were admitted to ICU between March 2020 and December 2020, were reviewed for presence of pneumothorax, pneumomediastinum and subcutaneous emphysema during their ICU stay. Demographic characteristics, mechanical ventilation settings, documented ventilation parameters, outcomes were studied.

A total of 161 patients were admitted to ICU during the study period, 96 were invasively ventilated. Nine patients had developed pneumothorax, pneumomediastinum and/or subcutaneous emphysema during their admission. Five of them were men and median age was 66.6 years. All patients 
were intubated and mechanically ventilated. All patients were managed conservatively. One patient was discharged from ICU, the others were lost due to other complications related to COVID-19. Upon detection of pneumothorax and/or mediastinum all patients were managed conservatively by limiting their PEEP and maximum inspiratory pressures and were followed by daily chest X-rays (CXR) for detection of any progress. None of the patients showed increase in size of their pneumothorax and/or pneumomediastinum. Hemodynamically instability due to pneumothorax and/or pneumomediastinum was not observed in any of the patients. Tension pneumothorax was not observed in any of the patients. Most common reason for death was sepsis due to secondary bacterial infections.

Acute deterioration with rapid oxygen desaturation or palpation of crepitation over thorax and neck in a COVID-19 patient should prompt a search for pneumothorax or pneumomediastinum. Conservative management may be an option as long as the patients are stable.

Key words: COVID-19; pneumothorax; pneumomediastinum

ÖZ

\section{COVID-19 pnömonisi ve pnömotoraks: olgu serisi}

Barotravma, kritik hastalarda farklı etiyolojilere bağı ARDS tablosunda sık bildirilen bir komplikasyon olup, \% 10 oranında olduğu bildirilmektedir. COVID-19 hastalarında pnömotoraks/pnömomediastinum daha yaygın görülmektedir ve farklı klinik özelliklere sahiptir. Burada, YBÜ'de kaldıkları süre boyunca pnömotoraks ve/veya pnömomediastinum gelişen 9 hastayı bildiriyoruz.

Mart 2020 ile Aralık 2020 arasında YBÜ'de takip edilen hastalar, kaldıkları süre boyunca pnömotoraks, pnömomediastinum ve subkutan amfizem gelişmesi açısından incelendi. Demografik özellikleri, mekanik ventilasyon ayarları, kaydedilen ventilasyon parametreleri, sağkalım durumları incelendi.

Çalışma süresince YBÜ'ye toplam 161 hasta kabul edildi, 96 hastaya invaziv mekanik ventilasyon uygulandı. Dokuz hastada pnömotoraks, pnömomediastinum ve/veya subkutan amfizem gelişti. Hastaların beşi erkekti ve ortanca yaş 66.6 yıldı. Tüm hastalar entübe edildi ve mekanik olarak havalandırıldı. Bir hasta YBÜ'den taburcu edildi, diğerleri COVID-19 ile ilgili diğer komplikasyonlar nedeniyle kaybedildi. Pnömotoraks ve/veya pnömomediastenin saptanması üzerine, tüm hastalar, PEEP ve maksimum inspiratuar basıņları sınırlandırılarak konservatif olarak tedavi edildi ve herhangi bir ilerlemenin tespiti için günlük gögüs röntgenleri (CXR) çekilerek izlendi. Hastaların hiçbirinde pnömotoraks ve/veya pnömomediastinum boyutlarında artış görülmedi. Hastaların hiçbirinde pnömotoraks ve/veya pnömomediastinuma bağlı hemodinamik instabilite gözlenmedi. Hiçbir hastada tansiyon pnömotoraks görülmedi. En yaygın ölüm nedeni, ikincil bakteriyel enfeksiyonlara bağlı sepsisti.

COVID-19 hastasında hızlı oksijen desatürasyonu ile akut kötüleşme veya toraks ve boyunda krepitasyon palpasyonu; pnömotoraks veya pnömomediastinum araştırması yapılmasını gerektirmelidir. Konservatif tedavi, hastalar stabil olduğu sürece bir seçenek olabilir.

Anahtar kelimeler: COVID-19; pnömotoraks; pnömomediastinum

\section{INTRODUCTION}

COVID-19 disease caused by the SARS-CoV-2 agent was firstly reported in Wuhan, China in December 2019, and in March 2020 it was declared by the World Health Organization as a viral pneumonia pandemia (1). Approximately $20 \%$ of patients are admitted to the intensive care units (ICU) due to complications of the infection and severe acute hypoxemic respiratory failure (1-3). Patients with ARDS are managed with lung protective mechanical ventilation practices restricting tidal volumes to $6 \mathrm{ml} / \mathrm{kg}$ and plateau pressures to $30 \mathrm{~cm} \mathrm{H}_{2} \mathrm{O}$, in line with the guideline recommendations. (4).

Barotrauma is a commonly reported complication in critically ill patients with ARDS caused by different etiologies, it's rate is reported to be around \%10. It is generally associated with higher airway pressures (5).
Pneumothorax and pneumomediastinum are defined as the presence of free air in the pleural and mediastinal cavities, respectively. Subcutaneous emphysema occurs when air gets into tissues under the skin. Both pneumothorax and pneumomediastinum are known complications of mechanical ventilation due to intubation. Even without barotrauma, pneumothorax or pneumomediastinum can be present in the COVID19 patients.

However, pneumothorax and pneumomediastinum in COVID-19 patients seem to be more common and have different clinical characteristics. Here we report 9 patients who had pneumothorax and/or pneumomediastinum during their stay in the ICU.

Patients admitted to the third level medical ICU of a university hospital, designated as the pandemia ICU, between March 2020 and December 2020, were reviewed for presence of pneumothorax, pneumome- 
diastinum and subcutaneous emphysema during their ICU stay. A general informed consent had been taken from relatives of each patients upon ICU admission for scientific use of their de-identified medical records. Demographic characteristics, mechanical ventilation settings, documented ventilation parameters, outcomes were studied.

A total of 161 patients were admitted to ICU during the study period, 96 were invasively ventilated. Nine patients ( $9 \%$ of mechanically ventilated) had developed pneumothorax, pneumomediastinum and/or subcutaneous emphysema during their admission. Five of them were men and median age was 66.6 years. All patients were intubated and mechanically ventilated.

One patient was discharged from ICU, the others were lost due to other complications related to COVID-19. Patients' characteristics are presented in Table 1. Routine treatment of critically ill COVID-19 patients included favipravir 2×1600 mg/day loading, followed by $2 \times 600 \mathrm{mg} /$ day for 10 days. Upon detection of pneumothorax and/or mediastinum all patients were managed conservatively by limiting their PEEP and maximum inspiratory pressures because the pneumomediastinum or pneumomediastinum was small. They were followed by daily chest X-rays (CXR) for detection of any progress. None of the patients showed increase in size of their pneumothorax and/ or pneumomediastinum. Hemodynamically instability due to pneumothorax and/or pneumomediastinum was not observed in any of the patients. Tension pneumothorax was not observed in any of the patients. Most common reason for death was sepsis due to secondary bacterial infections.

\section{Case 1}

77-year-old male, with diabetes mellitus (DM) and hypertension, was admitted to the ICU on the $2^{\text {nd }}$ day of hospitalization with due to increased oxygen need. High flow nasal oxygen therapy ( $\mathrm{HFNO})\left(\mathrm{FiO}_{2} 0.6\right.$ and $60 \mathrm{l} / \mathrm{min}$ flow) was started upon admission. He was intubated on the $2^{\text {nd }}$ day of ICU admission due to severe hypoxia $\left(\mathrm{SpO}_{2} \% 81\right.$ on $\mathrm{HFNC}$ with $\mathrm{FiO}_{2} 1$ and $60 \mathrm{l} / \mathrm{min}$ flow). Ventilator was set to PEEP: 14 $\mathrm{cmH}_{2} \mathrm{O}, \mathrm{Vt}: 6 \mathrm{ml} / \mathrm{kg}, \mathrm{FiO}_{2}: 0.6$ and peak inspiratory pressure was $23 \mathrm{cmH}_{2} \mathrm{O}$. On the subsequent day $\mathrm{SpO}_{2}$ was $93 \%$ with a PEEP of $10 \mathrm{cmH}_{2} \mathrm{O}$ and $\mathrm{FiO}_{2}$ of 0.6 . On the $4^{\text {th }}$ day of intubation, pneumothorax was detected on CXR performed for worsening hypoxemia and thoracic computed tomography (CT) was reported presence of pneumomediastinum and pneumothorax (Figure 1). He died on the $16^{\text {th }}$ day, because of multi-organ failure due to gram-negative sepsis.

\section{Case 2}

73-year-old male with hypertension and chronic obstructive pulmonary disease (COPD), was admitted to the ICU on his $7^{\text {th }}$ day in the wards because of increasing need for oxygen. He was administered dexamethasone $6 \mathrm{mg} /$ day and anakinra $200 \mathrm{mg} /$ day. On the $5^{\text {th }}$ day of ICU admission he was intubated. On the $9^{\text {th }}$ day desaturation developed. His PEEP was set to $8 \mathrm{cmH}_{2} \mathrm{O}$ and peak inspiratory pressure was 24 $\mathrm{cmH}_{2} \mathrm{O}$. CXR revealed pneumothorax. CT confirmed presence of pneumomediastinum and pneumothorax. He died on $10^{\text {th }}$ day of ICU.

\section{Case 3}

A 56-years-old female with hypertension and acute leukemia, was admitted to ICU on the $7^{\text {th }}$ day of hospitalization for increasing need of oxygen. Dexamethasone $6 \mathrm{mg} /$ day were administered. She was on HFNO until she was intubated on the $6^{\text {th }}$ day of ICU. Volume control mode with a PEEP of 10 $\mathrm{cmH}_{2} \mathrm{O}$; peak inspiratory pressure was $30 \mathrm{cmH}_{2} \mathrm{O}$. On the $12^{\text {th }}$ day of ICU, a crepitation was detected over the neck of the patient. Pneumothorax was observed in CXR (Figure 2). She died on $15^{\text {th }}$ ICU day.

\section{Case 4}

59-year-old male with hypertension, was readmitted due to severe hypoxemia 48 hours post-ICU discharge. He had been managed with HFNO in prone position on his first ICU admission and had received remdesivir in addition to favipiravir, anakinra $200 \mathrm{mg} /$ day and dexamethasone $6 \mathrm{mg} /$ day. He had been discharged on $3 \mathrm{lt} / \mathrm{min}$ oxygen by nasal cannula. His admission $\mathrm{PaO}_{2} / \mathrm{FiO}_{2}$ was 75 and had to be intubated rapidly. Control CXR after intubation revealed pneumothorax. He was managed on pressure control mode with a PEEP of PEEP: $8 \mathrm{cmH}_{2} \mathrm{O}$ and peak inspiratory pressure of $32 \mathrm{~cm} \mathrm{H}_{2} \mathrm{O}$, which was gradually decreased to $24 \mathrm{cmH}_{2} \mathrm{O}$ with prone positioning. A CT was performed on the $4^{\text {th }}$ day when crepitation over the neck was detected during daily physical examination. It revealed accompanying pneumomediastinum (Figure 3). He was discharged from ICU on day $15^{\text {th }}$. 


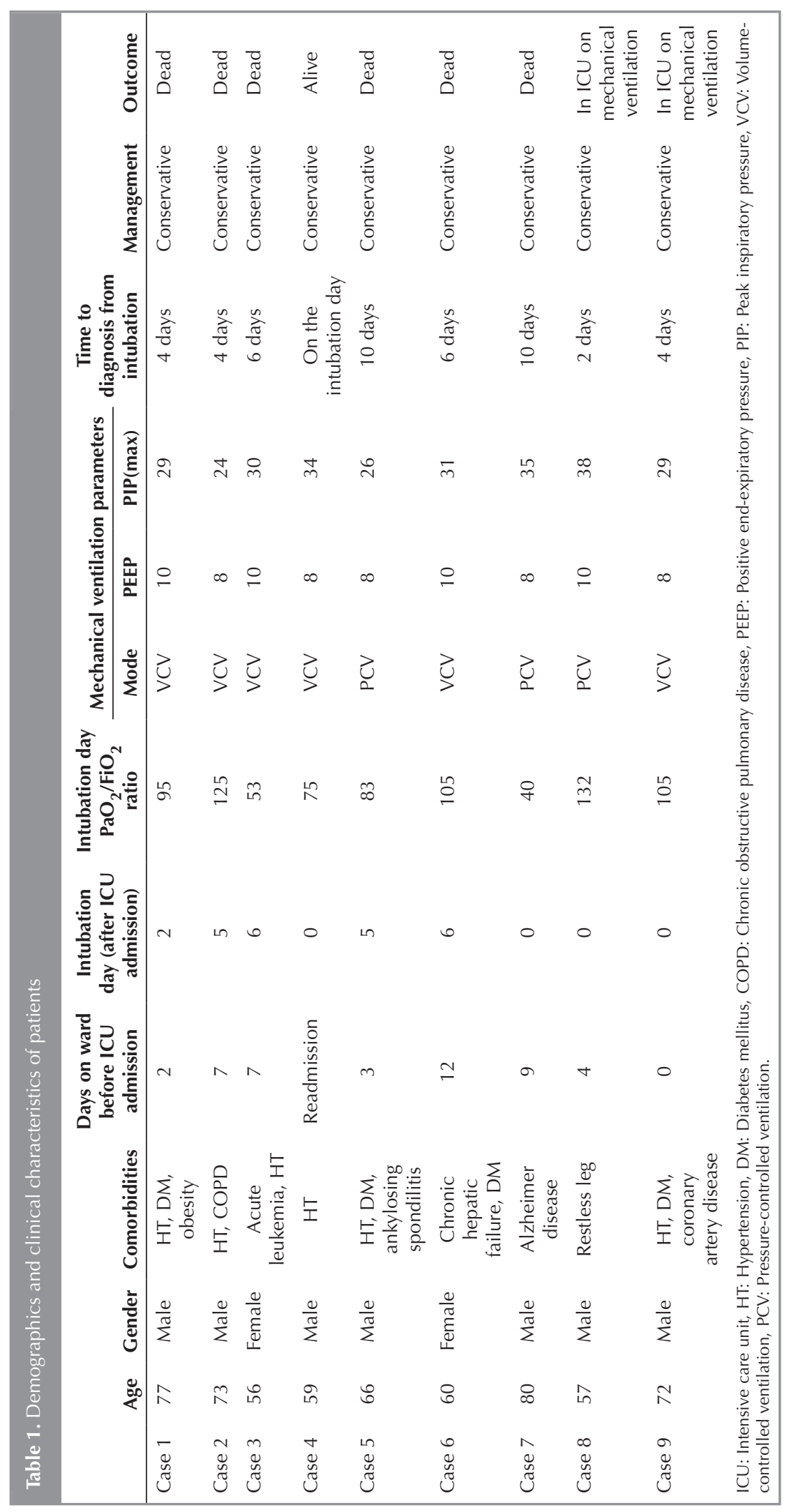

口440 Tuberk Toraks 2020;68(4):437-443 


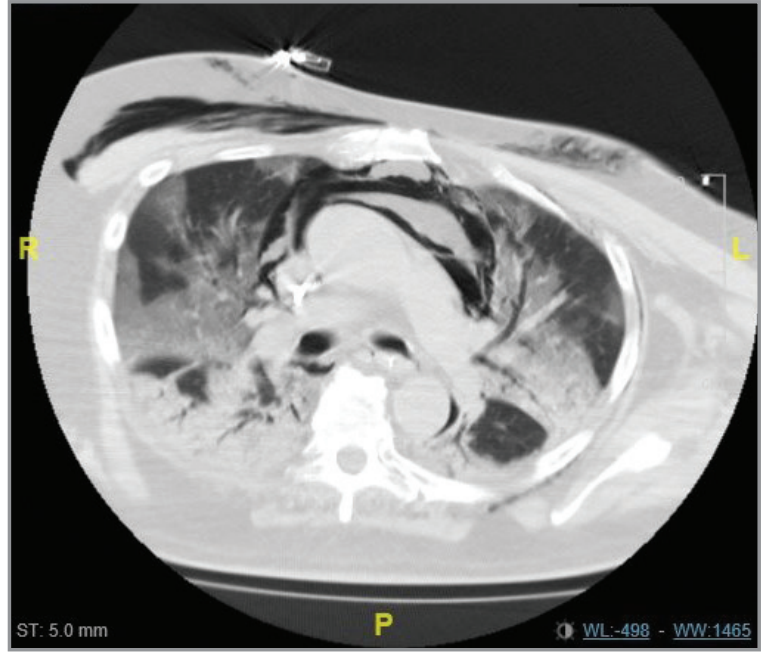

Figure 1. Thorax computed tomography shows pneumomediastinum.

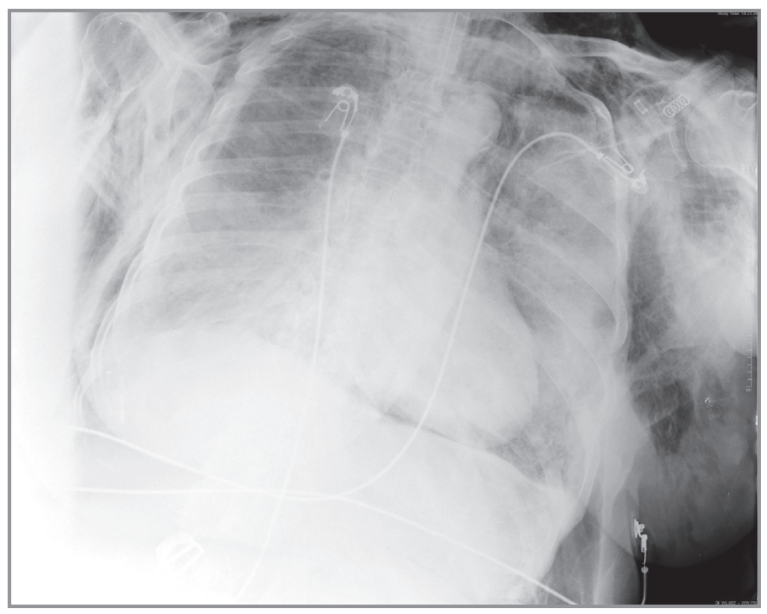

Figure 2. Chest $X$-ray indicates continuous diapraghm sign.

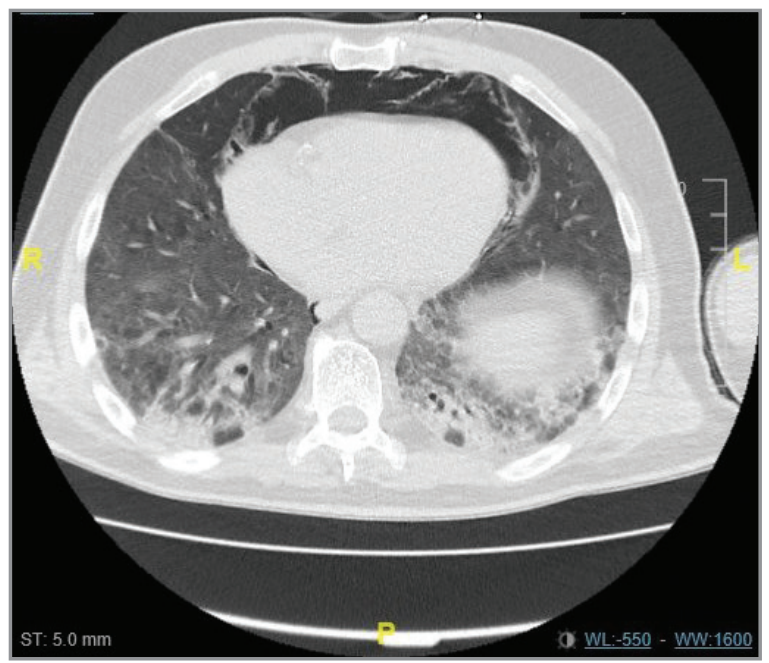

Figure 3. Thorax computed tomography.

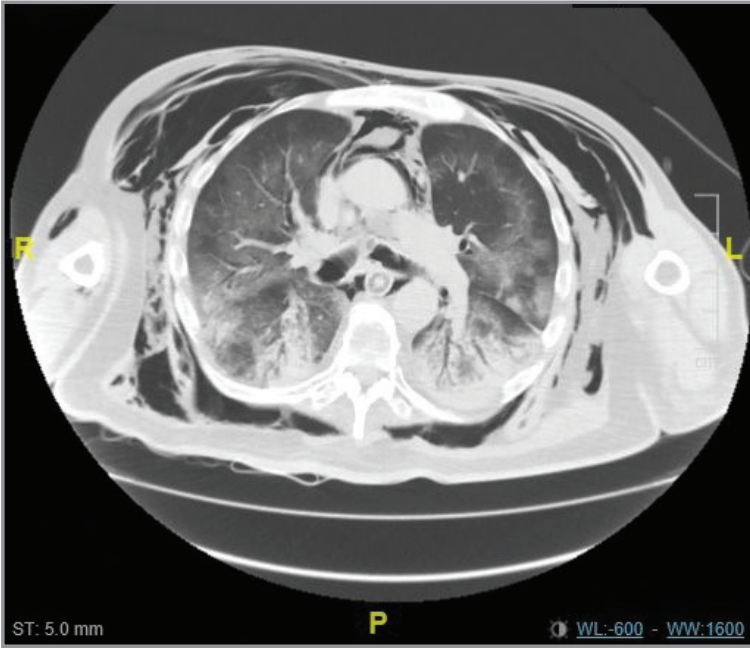

Figure 4. Thorax computed tomography shows extensive subcutaneous emphysema with pneumomediastinum.

\section{Case 5}

66-year-old male with DM, hypertension and ankylosing spondylitis was admitted to the ICU on the $3^{\text {rd }}$ day of his hospital admission. He was administered dexamethasone $1 \times 6 \mathrm{mg}$ and anakinra $200 \mathrm{mg}$ /day. He was on non-invasive mechanical ventilation (NIMV), when he was intubated on the $5^{\text {th }}$. On the $10^{\text {th }}$ day of intubation, under PEEP of $8 \mathrm{cmH}_{2} \mathrm{O}$ pneumothorax and pneumomediastinum were detected on CT (Figure 4). He died on $25^{\text {th }}$ day of $\mathrm{ICU}$.

\section{Case 6}

60-year-old female with DM, hypertension and chronic hepatic failure comorbidities was admitted to ICU from wards on $12^{\text {th }}$ day of hospitalization. She was treated with dexamethasone $1 \times 6 \mathrm{mg} /$ day and followed under NIMV. She was intubated on the $6^{\text {th }}$ day of ICU because of sudden hypoxemia and deterioration. On the $12^{\text {th }}$ day of ICU crepitation was detected over her neck. PEEP setting was $10 \mathrm{cmH}_{2} \mathrm{O}$. CXR detected pneumothorax. She died on $20^{\text {th }}$ day of ICU.

\section{Case 7}

80-year-old male with Alzheimer's disease was admitted to ICU on $9^{\text {th }}$ day of hospitalization. He was intubated upon ICU admission. On the $10^{\text {th }}$ day of intubation, subcutaneous crepitation over the neck region was detected and pneumomediastinum line was observed on the CXR. PEEP was set to 10 $\mathrm{CmH}_{2} \mathrm{O}$. He died on $24^{\text {th }}$ day of ICU. 


\section{Case 8}

57-year-old male with restless leg syndrome was admitted to ICU on his $4^{\text {th }}$ day on the wards. He was intubated on admission. On the $6^{\text {th }}$ day, CXR obtained after respiratory deterioration revealed subcutaneous emphysema and a linear band of mediastinal air. Ventilator settings were reviewed to decreased airway pressure. He is still on pressure control mechanical ventilation.

\section{Case 9}

72-year-old male with DM, hypertension, coronary artery disease was admitted to ICU from the emergency department and subsequently intubated. On the $4^{\text {th }}$ day, crepitation over thorax and neck were palpated. CT revealed subcutaneous emphysema and pneumomediastinum. He is still on pressure control mechanical ventilation.

\section{DISCUSSION}

Pneumothorax during mechanical ventilation is commonly associated with barotrauma due to high airway pressures. However, there are case reports on increased incidence of spontaneous and iatrogenic pneumothorax and/or pneumomediastinum in COVID-19 patients (6-8).

In a case series from the UK, pneumothorax and pneumomediastinum cases during COVID-19 pneumonia were reported (8). Seventy-one cases collected retrospectively from 16 different centers were analyzed. Remarkably, pneumothoraces in cases spontaneously breathing comprised almost 30\% of these patients. In our case series all patients, were intubated because of severe ARDS. Pneumothorax was detected in the first week of ICU admission, except for two. Median age was over 60 and mortality was high. UK case series reported that survival was higher $(70.9 \%$ vs $41.7 \%)$ in younger patients (<70 years) with pneumothorax and they also concluded that pneumothorax may not be a poor prognostic marker (8). However, gravity of our patients preclude us from making such a comment. They had severe ARDS, and most were complicated with secondary bacterial infections or cardiac involvement later in the disease course.

In another study from the USA, barotrauma due to invasive mechanical ventilation was observed in 89 of 601 (15\%) patients. The frequency of pneumothorax in mechanically ventilated patients with ARDS was reported to be significantly higher compared to the period before COVID-19 (9).

Interestingly, spontaneous pneumothorax has been reported even in patients who are not intubated during the course of COVID-19 $(8,10,11)$. As well, plateau pressures of our patients were generally lower than $30 \mathrm{cmH}_{2} \mathrm{O}$ and patients were deeply sedated. This leads to the questions: Does COVID-19 cause vulnerability for barotrauma? Should lower airway pressures be aimed for these patients?

It is hypothesized that cystic and fibrotic changes in the lung parenchyma that occur early during COVID19 course may be causing a vulnerability for pneumothoraces (8). These structural changes may be leading to alveolar tears. As well, it may be considered that mucus plugs may be facilitating local intra-alveolar pressure increases by acting as check-valves. Moreover, unlike non-COVID-19 patients, it was observed that lung tissue did not collapse enabling conservative management despite ongoing positive airway pressure ventilation. These points need further evaluation.

\section{CONCLUSION}

Acute deterioration with rapid oxygen desaturation or palpation of crepitation over thorax and neck in a COVID-19 patient should prompt a search for pneumothorax or pneumomediastinum. Conservative management may be an option as long as the patients are stable and no progression is seen.

\section{CONFLICT of INTEREST}

The authors reported no conflict of interest related to this article.

\section{AUTHORSHIP CONTRIBUTIONS}

Concept/Design: LT, NDA

Analysis/Interpretation: LT, FGSS, UE

Data Acquisition: LT, FGSS, UE,

Writing: LT, NDA

Critical Revision: LT, IAK, MBY, CY, NDA

Final Approval: LT, CY, NDA

\section{REFERENCES}

1. World Health Organization (WHO). Clinical management of severe acute respiratory infection (SARI) when covid19 disease is suspected: Interim guidance. Available from: https://www.who.int/emergencies/diseases/novelcorona virus-2019 Accessed date: March 142020. 
2. Wu Z, McGoogan MM. characteristics of and important lessons from the coronavirus disease 2019 (COVID-19) outbreak in China: summary of a report of 72314 cases from the Chinese center for disease control and prevention. JAMA 2020; 323: 1239-42.

3. Halaclı B, Kaya A, Topeli A. Critically ill COVID-19 patient. Turk J Med Sci 2020; 50(SI-1): 585-91.

4. Alhazzani W, Møller MH, Arabi YM, Loeb M, Gong MN, Fan $E$, et al. Surviving sepsis campaign: guidelines on the management of critically ill adults with coronavirus disease 2019 (COVID-19). Crit Care Med 2020; 48(6): e440-e69.

5. Diaz R, Heller D. Barotrauma and Mechanical Ventilation. In: Treasure Island StatPearls. (FL): StatPearls Publishing; August 8, 2020.

6. Ucpinar BA, Sahin C, Yanc U. Spontaneous pneumothorax and subcutaneous emphysema in COVID-19 patient: case report. J Infect Public Health 2020; 13(6): 887-9.
7. Shan S, Guangming L, Wei L, Xuedong Y. Spontaneous pneumomediastinum, pneumothorax and subcutaneous emphysema in COVID-19: case report and literature review. Rev Inst Med Trop Sao Paulo 2020; 62: e76.

8. Martinelli AW, Ingle T, Newman J, Nadeem I, Jackson K, Lane ND. COVID-19 and pneumothorax: a multicentre retrospective case series. Eur Respir / 2020; 56(5): 2002697.

9. McGuinness G, Zhan C, Rosenberg N. Increased incidence of barotrauma in patients with COVID-19 on invasive mechanical ventilation. Radiology 2020; 297(2): e252-e62.

10. Ferreira $J G$, Rapparini $C$, Gomes BM, Pinto LAC, Freire MSDSE. Pneumothorax as a late complication of COVID19. Rev Inst Med Trop Sao Paulo 2020; 62: e61.

11. Mallick T, Dinesh A, Engdahl R, Sabado M. COVID-19 complicated by spontaneous pneumothorax. Cureus 2020; 12(7): e9104. 